\title{
THE EFFECT OF SKIM MILK CONCENTRATION ON SENSORY QUALITY AND pH OF PROBIOTIC YOGHURT ADDED WITH RED DRAGON FRUIT (Hylocereus polyrhizus)
}

\author{
Asterias Hafiizha $^{1)}$, Indira Lanti Kayaputri ${ }^{1)}$, Tensiska ${ }^{1)}$, Nur Risma Amalia ${ }^{1)}$ \\ 1) Departemen Teknologi Industri Pangan, Fakultas Teknologi Industri Pangan, University Padjadjaran, Jalan \\ Raya Bandung-Sumedang Km. 21, Jatinangor, Sumedang \\ Email: Asterazha@gmail.com cc: Indira.lanti@unpad.ac.id
}

Submitted 11 September 2019; Accepted 20 February 2020

\begin{abstract}
Probiotic yoghurt is one of dairy products that has benefits to the human health. This research aimed to understand the effect of skim milk concentration on the sensory quality traits and $\mathrm{pH}$ of probiotic yoghurt added with red dragon fruit (Hylocereus polyrhizus) dices prior to the fermentation. The research method was experimental method with 4 treatments and 3 replications in a completely randomized group design. The data were analyzed using one-way analysis of variance followed by Duncan's multiple range test at $\mathrm{P}<0.05$. The treatment in this research was different addition levels of skim milk $(3 \%, 5 \%, 7 \%$, and $9 \%)$ to yoghurt. The $\mathrm{pH}$, color, aroma, taste, texture, viscosity and overall acceptance were assessed. The addition of skim milk increased $(\mathrm{P}<0.05)$ the acceptability of flavor, texture, viscosity and overall acceptance, in which the addition of skim milk at $9 \%$ showed the highest acceptability of taste. However, different addition level of skim milk did not significantly affect $\mathrm{pH}$ and the acceptability of color and aroma of yoghurt. The $\mathrm{pH}$ of yogurt ranged from 4.06 to 4.26. In addition, the color and aroma of yogurt were in the scale of neither like or dislike, the texture was in the scale of dislike to like, taste, viscosity and overall acceptance were in the scale of dislike to neither like nor dislike. In conclusion, skim milk should be used for producing yogurt with red dragon fruit at $9 \%$ of whole milk to obtain acceptable product.
\end{abstract}

Keywords: $\mathrm{pH}$ value; sensory; skim milk; probiotic yoghurt 


\section{INTRODUCTION}

Yoghurt is believed to contain good nutritions and benefits, especially for the digestive tract and immune system improvements due to the activity of good bacteria. Yoghurt is produced using whole or skim milk and inoculated with lactic acid bacteria, i.e. Streptococcus thermophilus and Lactobacillus bulgaricus as a starter. Lactobacillus achidophilus is classified into probiotics and are used in making probiotic yoghurt. Probiotics will produce natural antibiotics that help maintain the integrity of the intestinal mucosa, help in the process of food metabolism and enhance immunity (Winarno and Fernandez, 2007). Lactic acid bacteria that produce this unique yoghurt product require nutrients for growth that are obtained from milk.

Skim milk is a part of milk that contains most of milk protein, and all the nutrients from milk except fat and fatsoluble vitamins (Muchtadi, 2013). The use of skim milk, which is rich in lactose, is purposed not only to increase the level of yoghurt total solids, thus resulting good characteristics, but also as a source of nutrition for microorganisms growth during fermentation. The addition of skim milk can increase protein content of yoghurt. The increasing protein content will increase the total milk solids which will then affect the viscosity of fermented milk. Further, the higher the total milk solids are, the higher the total acid will be produced (Tamime dan Robinson, 2000).

Dragon fruit is one of the fruits that is nutritious and can benefit human health. Dragon fruit is useful for increasing endurance, maintaining healthy cardiovascular system, preventing colon cancer and reducing body fat. Dragon fruit

*Corresponding author:

Asterias Hafiizha

Email: asterazha@gmail.com

Departemen Teknologi Industri Pangan, Fakultas Teknologi Industri Pangan, University Padjadjaran, Jalan Raya Bandung-Sumedang Km. 21, Jatinangor, Sumedang has a variety of nutrients, which are a source of fiber, vitamins, minerals, carbohydrates, proteins, and antioxidants. Antioxidants are substances that can inhibit the process of aging or cells apoptosis (Ashari, 2004). Probiotic yoghurt added with dragon fruit dices is one of the new alternatives of yoghurt products that provides nutritional benefits for consumers. Probiotic yoghurt added with red dragon fruit is produced by the addition of dragon fruit dices before the fermentation process to produce probiotic yoghurt that has good characteristics and process efficiency, while the addition of skim milk as a source of nutrients for microorganisms. The purpose of this study was to determine the effect of skim milk concentration on the sensory quality characteristics and $\mathrm{pH}$ of probiotic yoghurt added with red dragon fruit.

\section{MATERIALS AND METHODS}

\section{Materials}

The research method used was an experimental method in randomized group design followed with one-way analysis variance and Duncan's multiple range test. This study consisted of 4 treatments and 3 replications. The treatments were different skim milk concentrations; $3 \%, 5 \%, 7 \%$, and $9 \%$. The ingredients used are red dragon fruit M'Yoghurt SME (Cimahi), sucrose, freeze dried starter yogourt, whole cow milk from KSPBU Lembang, skim milk, buffer $\mathrm{pH} 4$ and $\mathrm{pH} \mathrm{7,} \mathrm{distilled} \mathrm{water.} \mathrm{The} \mathrm{tools}$ used were stoves, pans, refrigerators, incubators, jar bottles, and $\mathrm{pH}$ meters.

\section{Dragon fruit dices preparation}

Ripe red dragon fruit was peeled and then cut into small dice of approximately $2 \times 1.5 \mathrm{~cm}$. Sucrose was dissolved in water at

How to cite:

Hafiizha, A., Kayaputri, I. L., Tensiska., \& Amalia, N. R. (2020). The effect of skim milk concentration on sensory quality and $\mathrm{pH}$ of probiotic yoghurt added with red dragon fruit (Hylocereus polyrhizus). Jurnal Ilmu dan Teknologi Hasil Ternak, 15 (1), 52-60 
a ratio of $1: 2$, then mixed with dragon fruit until submerged. Sucrose solution was used $4 \%$ for every $10 \%$ dice of dragon fruit.

\section{Probiotic yoghurt preparation}

Whole cow's milk and skim milk of various concentrations were mixed before pasteurization at $60^{\circ} \mathrm{C}$ for $30 \mathrm{~min}$. After that, the temperature was reduced to $41^{\circ} \mathrm{C}$. The starter culture (5\% of whole milk) consisting of Streptococcus thermophilus, Lactobacillus bulgaricus, and Lactobacillus achidophilus, was inoculated by dissolving in part of pasteurized milk, poured to the rest of milk and stirred for $1 \mathrm{~min}$. The dragon fruit dices and sugar solution that had been made previously was added to a sterile jar. Inoculated milk was then added into the jar that had been filled with dragon fruit. Incubation was carried out at $41^{\circ} \mathrm{C}$ for $6 \mathrm{~h}$. After incubation, the yoghurt was put in the refrigerator at $5^{\circ} \mathrm{C}$ for $12-14 \mathrm{~h}$ prior to analysis.

\section{Measurement of $\mathrm{pH}$ value}

The measurement of $\mathrm{pH}$ values was performed using a $\mathrm{pH}$ meter. Firstly, the $\mathrm{pH}$ meter was calibrated using a buffer solution of $\mathrm{pH} 7$ and $\mathrm{pH} 4$. The electrodes was then cleaned using distilled water. After the calibration was done, the sample that had been prepared as much as $10 \mathrm{~mL}$ was dipped with the electrode until the value indicated by $\mathrm{pH}$ meter was stable. The electrode was washed again using distilled water prior to next measurement.

\section{Sensory quality assessment}

Sensory quality assessment was conducted using hedonic or preference scales; like and dislike (Stone and Joel, 2012). The panelists were semi-trained panelists with a total of 15 panelists. The variables tested on each panelist included color, aroma, flavour, texture, viscosity and overall acceptance.

This test was carried out by presenting 4 yoghurt samples in a plastic cup that was uniformly colored and randomly coded. Then, the panelists were asked to give a score to the sample with a level of preference based on a scale of 5) like very much, 4) like, 3) neither like nor dislike, 2) dislike, and 1) dislike very much.

\section{RESULTS AND DISCUSSION}

\section{pH Value}

The quality of a yoghurt can be assessed by knowing the value of the $\mathrm{pH}$ of which is related to the acid content accumulated during the fermentation process by lactic acid bacteria. The results of measurements of the $\mathrm{pH}$ value of probiotic yoghurt added with red dragon fruit with the different levels of skim milk are shown in Table 1.

The addition of skim milk had a significant effect $(\mathrm{P}<0.05)$ on $\mathrm{pH}$. The $\mathrm{pH}$ value of yoghurt ranged from 4.06 to 4.26 , which is within the acceptable range. The standard $\mathrm{pH}$ of yoghurt is around 3.8 to 4.6 according to Surayah and Sugiarto (2005). Septiani et al. (2013) mentioned that the addition of skim milk can reduce the $\mathrm{pH}$ of yoghurt because of the high content of lactose, resulting in higher lactic acid. During the fermentation process, lactic acid bacteria require energy from the milk which will be metabolized into lactic acid.

During fermentation, lactose and protein have an important role as the carbon source that will be metabolized into lactic acid and reduce $\mathrm{pH}$, while protein as a trigger for bacterial growth (Sintasari et al., 2014). Sunarlim and Setiyanto (2008) stated that the combination of $S$. thermophillus and L. acidophillus as yoghurt starter would increase lactic acid and cause a rapid decrease in $\mathrm{pH}$ value. Lactic acid causes a decrease in $\mathrm{pH}$ value, the value is determined due to the presence of $\mathrm{H}^{+}$ions so that the $\mathrm{pH}$ gets lower (Burton, 2014).

\section{Sensory Quality}

Sensory or organoleptic test is needed to determine the preference of consumers. The variables tested in this study includes color, aroma, flavor, texture, viscosity, and overall acceptance. 


\section{Color preferences}

Color is one of the quality attributes assessed in sensory testing of a food ingredient. Color is important in determining quality because consumers will notice firstly and get a first impression based on the color seen. The results of the calculation of the color characteristics of probiotic yoghurt added with red dragon fruit with different levels of skim milk are shown in Table 2.

Different addition levels of skim milk had no significant effect on the color of the yogurt. The added skim milk does not provide a color difference on yoghurt. The resulting color of yoghurt was influenced by a mixture of sugar solution and dragon fruit dices instead.

Table 1. The Effect of Skim Milk Concentration on The $\mathrm{pH}$ Value of Probiotic Yoghurt Added with Red Dragon Fruit

\begin{tabular}{cc}
\hline Skim milk concentration & $\mathrm{pH}$ value \\
\hline $3 \%$ & $4.11 \pm 0.05^{\mathrm{a}}$ \\
$5 \%$ & $4.10 \pm 0.11^{\mathrm{a}}$ \\
$7 \%$ & $4.10 \pm 0.11^{\mathrm{a}}$ \\
$9 \%$ & $4.26 \pm 0.31^{\mathrm{a}}$ \\
\hline
\end{tabular}

Remarks: Data are presented as mean \pm standard deviation. The mean marked with the same letter stated no significant difference at the test level of 5\% according to the Duncan test.

Table 2. The Effect of Skim Milk Concentration on The Color Preference Score of Probiotic Yoghurt Added with Red Dragon Fruit

\begin{tabular}{ccc}
\hline Skim milk concentration & Score & Score description \\
\hline $3 \%$ & $3.27 \pm 1.53^{\mathrm{a}}$ & Neither like nor dislike \\
$5 \%$ & $3.27 \pm 1.10^{\mathrm{a}}$ & Neither like nor dislike \\
$7 \%$ & $3.53 \pm 1.06^{\mathrm{a}}$ & Like \\
$9 \%$ & $3.27 \pm 0.96^{\mathrm{a}}$ & Neither like nor dislike \\
\hline
\end{tabular}

Remarks: Data are presented as mean \pm standard deviation. The mean marked with the same letter stated no significant difference at the test level of 5\% according to the Duncan test.

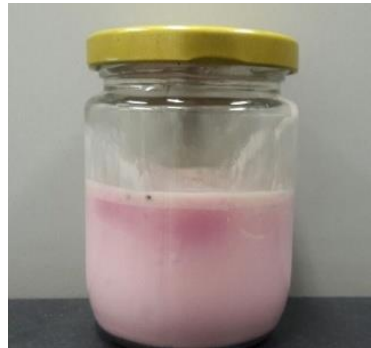

(a)

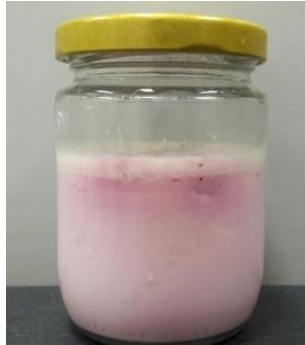

(b)

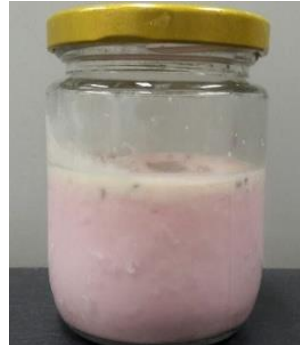

(c)

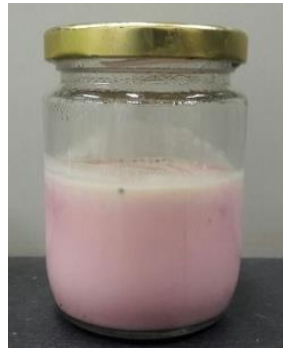

(d)

Remark: (a) Skim Milk 3\% (b) Skim Milk 5\% (c) Skim Milk 7\% (d) Skim Milk 9\%

Figure 1. Probiotic Yoghurt Added with Red Dragon Fruit Made with Different Levels of Skim Milk

Figure 1 shows the appearance of probiotic yoghurt added with red dragon fruit with different concentrations of skim milk. The color of probiotic yoghurt added with dragon fruit was pink. The red pigment is derived from the red dragon fruit which is added before fermentation. Red dragon fruit contains a red pigment derived from betacyanin in its flesh, which is watersoluble (Wybraniec et al., 2007). The purple 
pigment of red dragon fruit flesh is a derivative of betalain. Betalain has been investigated for its benefits as an antiradical and antioxidative compound (Pertiwi and Noer, 2014).

\section{Aroma preferences}

Another attribute that is important in consumer acceptance is aroma. The aroma can be a determinant of the quality of a food because it is an indicator that is known quickly by panelists. The preference scores of the aroma of probiotic yoghurt added with red dragon fruit with different levels of skim milk are shown in Table 3.
Different levels of skim milk gave no significant effect on the aroma of the yoghurt. The aroma of yoghurt was typical sour like yoghurt in general so that panelists did not notice any differences. The volatile compounds produced by lactic acid bacteria in yoghurt give the tangy aroma characteristic (Widodo, 2003). The generation of tangy aroma in yoghurt is caused by bacteria that produce organic acids. The tangy aroma of yoghurt is due to the acid compounds produced during fermentation are accumulating by the growth of lactic acid bacteria (Handayani, 2017).

Table 3. The Effect of Skim Milk Concentration on The Aroma Preference of Probiotic Yoghurt Red Dragon Fruit

\begin{tabular}{ccc}
\hline Skim milk concentration & Score & Score description \\
\hline $3 \%$ & $3.07 \pm 0.70^{\mathrm{a}}$ & Neither like nor dislike \\
$5 \%$ & $3.27 \pm 1.10^{\mathrm{a}}$ & Neither like nor dislike \\
$7 \%$ & $3.67 \pm 0.90^{\mathrm{a}}$ & Like \\
$9 \%$ & $3.53 \pm 0.99^{\mathrm{a}}$ & Like
\end{tabular}

Remarks: Data are presented as mean \pm standard deviation. The mean marked with the same letter stated no significant difference at the test level of $5 \%$ according to the Duncan test.

\section{Taste preferences}

Taste has an important role in determining consumer acceptance. Taste attributes of yoghurt are influenced by several factors, including the ability of bacteria used as a culture for lactose breakdown (Lestari et al., 2011). The preference scores of the taste of probiotic yoghurt added with red dragon fruit with different levels of skim milk are shown in Table 4.

Different levels of skim milk had a significant effect $(\mathrm{P}<0.05)$ on the taste of yoghurt. The taste of the yoghurt was sour without any other taste although sucrose was added into red dragon fruit dices. The sour taste comes from the formation of lactic acid during fermentation. Acid produced by bacteria during fermentation increases and affects the $\mathrm{pH}$, total acid content and total dissolved solids. The addition of skim milk can add more lactose for lactic acid bacteria which will produce lactic acid and cause a decrease in $\mathrm{pH}$, increase the total acid content, and more intense acidic aroma and taste. Miwada et al., (2006) mentioned that lactic acid bacteria convert lactose into organic acids.

Lactic acid formed is the result of bacterial metabolism in fermented milk where lactose is the source of carbon (Ginting and Pasaribu, 2005). This acid is also related to the result of total dissolved solids which according to Sintasari (2014) that the higher skim milk is added, the higher the total dissolved solids is produced. 
Table 4. The Effect of Skim Milk Concentration on The Taste Preference Score of Probiotic Yoghurt Added with Red Dragon Fruit

\begin{tabular}{ccc}
\hline Skim milk concentration & Score & Score description \\
\hline $3 \%$ & $2.47 \pm 0.99^{\mathrm{b}}$ & Dislike \\
$5 \%$ & $2.87 \pm 0.92^{\mathrm{ab}}$ & Neither like nor dislike \\
$7 \%$ & $3.27 \pm 0.88^{\mathrm{ab}}$ & Neither like nor dislike \\
$9 \%$ & $3.00 \pm 1.13^{\mathrm{a}}$ & Neither like nor dislike \\
\hline
\end{tabular}

Remarks: Data are presented as mean \pm standard deviation. The mean marked with the same letter stated no significant difference at the test level of $5 \%$ according to the Duncan test.

\section{Texture preferences}

The texture of yoghurt is one of the attributes that influence consumer acceptance. Acceptable texture of yoghurt is not split or homogeneous without excess whey. The preference scores of the texture of probiotic yoghurt added with red dragon fruit with different levels of skim milk are shown in Table 5.

Different levels of skim milk had a significant effect on the texture of yoghurt. The yoghurt in this study had a fairly thick texture that is affected by the addition of skim milk. As the total solid was increased, the texture of yoghurt was more acceptable. According to Djaafar and Rahayu (2006), protein reaches its isoelectric point at $\mathrm{pH}$ of 4.4-4.5, resulting in protein coagulation and the milk becomes semi-solid. Krisnaningsih and Efendi (2015) reported that the addition of total solids such as skim milk, sodium caseinate, whey protein concentrate in lowfat yoghurt aims to prevent texture damage due to low gel formation and high separation of whey on the surface of the yoghurt.

\section{Viscosity preferences}

Yoghurt viscosity is a semi solid dairy product that is thick and dense liquid. Just like the texture preferences, the viscosity of the yoghurt will affect consumer acceptance. The viscosity of yoghurt depends on its type; drink yoghurt, yoghurt set, stirred yoghurt, and frozen yoghurt. The preference scores of the viscosity of probiotic yoghurt added with red dragon fruit with different levels of skim milk are shown in Table 6.

Different levels of skim milk affected the viscosity of yoghurt. The viscosity of the yoghurt is different from the texture in the mouth. The viscosity produced from yoghurt with the addition of skim milk has a high viscosity which can be seen from the total dissolved solids. The texture of yoghurt is determined by the protein dissolved in milk that plays a role when undergoing denaturation to form a gel due to heating, with temperatures up to $8^{\circ} \mathrm{C}$ making the texture stable to become semi-solid and increase viscosity.

Table 5. The Effect of Skim Milk Concentration on The Texture Preference Score of Probiotic Yoghurt Added with Red Dragon Fruit

\begin{tabular}{ccc}
\hline Skim milk concentration & Score & Score description \\
\hline $3 \%$ & $2.33 \pm 0.90^{\mathrm{c}}$ & Dislike \\
$5 \%$ & $3.13 \pm 1.25^{\mathrm{b}}$ & Neither like nor dislike \\
$7 \%$ & $4.13 \pm 0.64^{\mathrm{ab}}$ & Like \\
$9 \%$ & $3.60 \pm 0.99^{\mathrm{a}}$ & Like \\
\hline
\end{tabular}

Remarks: Data are presented as mean \pm standard deviation. The mean marked with the same letter stated no significant difference at the test level of 5\% according to the Duncan test. 
Table 6. The Effect of Skim Milk Concentration on The Viscosity Preference Score of Probiotic Yoghurt Added with Red Dragon Fruit

\begin{tabular}{ccc}
\hline Skim milk concentration & Score & Score description \\
\hline $3 \%$ & $2.20 \pm 1.21^{\mathrm{b}}$ & Dislike \\
$5 \%$ & $3.33 \pm 1.35^{\mathrm{a}}$ & Neither like nor dislike \\
$7 \%$ & $3.93 \pm 0.96^{\mathrm{a}}$ & Like \\
$9 \%$ & $3.60 \pm 0.99^{\mathrm{a}}$ & Like \\
\hline
\end{tabular}

Remarks: Data are presented as mean \pm standard deviation. The mean marked with the same letter stated no significant difference at the test level of $5 \%$ according to the Duncan test.

Table 7. The Effect of Skim Milk Concentration on Overall Acceptance Score of Probiotic Yoghurt Added with Red Dragon Fruit

\begin{tabular}{ccc}
\hline Skim milk concentration & Score & Score description \\
\hline $3 \%$ & $2.73 \pm 1.44^{\mathrm{b}}$ & Neither like nor dislike \\
$5 \%$ & $3.47 \pm 0.99^{\mathrm{a}}$ & Neither like nor dislike \\
$7 \%$ & $3.73 \pm 0.96^{\mathrm{a}}$ & Like \\
$9 \%$ & $3.67 \pm 0.62^{\mathrm{a}}$ & Like \\
\hline
\end{tabular}

Remarks: Data are presented as mean \pm standard deviation. The mean marked with the same letter stated no significant difference at the test level of 5\% according to the Duncan test.

The $\mathrm{pH}$ of the yoghurt that changes also plays a role in determining the solubility of the casein which results in the aggregatation of the casein (Purbasari et al., 2014).

\section{Overall acceptance preferences}

The overall acceptance is the final assessment based on all the attributes that have been assessed namely color, aroma, taste, texture and viscosity. The overall acceptance becomes the main assessment by consumers who will provide an assessment of the product. The overall acceptance preference scores of probiotic yoghurt added with red dragon fruit with different levels of skim milk are shown in Table 7.

Different levels of skim milk affected the overall acceptance score of yoghurt. A skim concentration of $3 \%$ showed a significantly different as compared to higher concentrations, while between 5\% and $9 \%$ showed no differences. Acording to Hafiyatunnisa (2014), the addition of skim milk at $7 \%$ to the yoghurt added with jackfruit seed results in preferable color, taste, viscosity and overall acceptance and meet the standard of total dissolved solids, which is at least $8.2^{\circ}$ brix.

\section{CONCLUSION}

Based on the results of the study, it can be concluded that the addition of skim milk concentration at $9 \%$ of whole milk increases the preferences of taste, texture, viscosity and overall acceptance of probiotic yoghurt added with red dragon fruit, without altering the $\mathrm{pH}$ value, color and aroma preferences. Further research is needed to study the addition of sugar solution and dragon fruit added so that it can improve the taste of yoghurt with acceptable sweet taste and is preferred by panelists.

\section{ACKNOWLEDGEMENT}

Thank you to all laboratory assistants and all staff of the Department of Food Industry Technology, Faculty of Agricultural Industrial Technology, Padjadjaran University, who have helped and provided facilities in the course of this research. 


\section{REFERENCE}

Ashari, S. (2004). Biologi Reproduksi Tanaman Buah-buahan Komersial. Malang: Bayumedia Publishing.

Burton, E. (2014). Formulasi Yoghurt Probiotik Karbonasi dan Potensi Sifat Fungsionalnya [Tesis]. Jurnal Ilmu Produksi Dan Teknologi Hasil Peternakan, 02(1), 2014.

Djaafar, T. F., \& Rahayu, E. S. (2006). Karakteristik yogurt dengan inokulum lactobacillus yang diisolasi dari makanan fermentasi tradisional. Agros.

Ginting, N., \& Pasaribu, E. (2005). Pengaruh temperatur dalam pembuatan yoghurt dari berbagai jenis susu dengan menggunakan lactobacillus bulgaricus dan streptococcus. Journal Agribisnis Peternakan, 1.

Hafiyatunnisa, R. (2014). Skripsi Kajian Beberapa Karakteristik Yoghurt Biji Nangka Pada Berbagai Konsentrasi Susu Skim dan Starter. Universitas Padjadjaran, Jatinangor.

Handayani, Z. (2017). Uji organoleptik dan kadar glukosa yoghurt kulit semangka dengan substitusi pemanis sukrosadan ekstrak daun stevia (Stevia rebaudiana). URECOL, 147-156.

Krisnaningsih, A. T. N., \& Efendi, A. (2015). Pengaruh penggunaan level susu skim dan masa inkubasi pada suhu ruang terhadap $\mathrm{pH}$ dan organoleptik. FPMIPA Jember, ISSN 2086-.

Lestari, N. P. A., Dewanti-Hariyadi, R., \& Desnilasari, D. (2011). Formulation of Synbiotic Yoghurt Made With Banana Puree and Inulin. Institut Pertanian Bogor.
Miwada, I. N. S., Lindawati, S. A., \& Tatang, W. (2006). Tingkat efektivitas "starter" bakteri asam laktat pada proses fermentasi laktosa susu. Journal of the Indonesian Tropical Animal Agriculture, 31(1), 1-4.

Muchtadi, D. (2013). Prinsip Teknologi Pangan Sumber Protein. Bandung: Alfabeta, CV.

Pertiwi, W. A., \& Noer, E. R. (2014). Pengaruh pemberian jus buah naga merah (Hylocereus polyrhizus) terhadap kadar HDL pria dislipidemia. Journal of Nutrition College, 3, 706-714.

Purbasari, A., Pramono, Y. B., \& Muhammad, B. (2014). Nilai pH, kekentalan, citarasa asam, dan kesukaan pada susu fermentasi dengan perisa alami jambu air (Syzygium sp). Jurnal Aplikasi Teknologi Pangan, 3(4), 174-177.

Septiani dkk. (2013). Pengaruh penambahan susu skim pada proses pembuatan frozen yoghurt yang berbahan dasar whey terhadap total asam, $\mathrm{pH}$, dan jumlah bakteri asam laktat. Animal Agriculture Journal, 2(1), 225-231.

Sintasari, R. A. (2014). Pengaruh penambahan konsentrasi susu skim dan sukrosa terhadap karakteristik minuman probiotik sari beras merah. Jurnal Pangan Dan Agroindustri, 2(3), 65-75.

Stone, H., \& Sidel, J. L. (2012). Sensory Evaluation Practices: Food and Science Technology Series. $2^{\text {nd }}$ Edition. San Diego: California. Academic Press Inc.

Sunarlim, R., \& Setiyanto, H. (2008). Pengaruh Kombinasi Lactobacillus Acidophilus Dengan Starter Yoghurt (Lactobacillus bulgaricus dan Streptococcus thermophilus) Terhadap Mutu Susu 
Fermentasi. Seminar Nasional Teknologi Peternakan Dan Veteriner.

Surayah, A., \& Sugiarto. (2005). Uji kimiawi dan organoleptik sebagai uji mutu yoghurt. Prosiding Temu Teknis Nasional Tenaga Fungsional Pertanian, 108-113.

Widodo. (2003). Bioteknologi Industri Susu. Depok, Jawa Barat: Lacticia Press.
Winarno, F. G., \& Fernandez, I. E. (2007). Susu dan Produk Fermentasinya. Bogor: M-Brio Press.

Wybraniec, S., Nowak-Wydra, B., Mitka, K., Kowalski, P., \& Mizrahi, Y. (2007). Minor betalains in fruits of hylocereus species. Phytochemistry, 68, 251-259. 